\title{
Vehicle accident frequencies on the example of Poland and Slovakia in 2010-2020
}

\author{
Damian Frej ${ }^{* 1}$, Marek Jaśkiewicz ${ }^{1}$ \\ ${ }^{1}$ University of the Kielce University of Technology, Department of Automotive Engineering end \\ Transport, Avenue Tysiąclecia Państwa Polskiego 7, 25-314 Kielce, Poland
}

\begin{abstract}
Research background: The article presents a general description of the safety problem in Polish and Slovak road transport in 2010-2020. Poland and Slovakia, as neighboring countries of the European Union, are connected with each other by the trade route (Baltic-Adriatic). Moreover, it should be noted that in 2019, the trade turnover between Poland and Slovakia amounted to EUR 10.35 billion. Poland is the third largest trade partner of Slovakia. The energy and automotive industries are among the most promising commercial areas of these countries. The downward trend in the number of accidents and fatalities shows Slovakia and Poland at the same level of safety.

Purpose of the article: The main aim of the article is to discuss the topic of road accidents in Poland and Slovakia, taking into account the perspectives of "Vision Zero". Because both Poland and Slovakia, along with other European Union Member States, are required to reduce the number of road fatalities by 2030 and eliminate them completely by 2050 .

Methods: The article presents a statistical analysis of road accidents in Poland and Slovakia in 2010-2020. Based on statistical data, a road accident forecast for 2020-2030 has been prepared.

Findings \& Value added: Forecasts for the number of people killed in road accidents estimate that in 203029 people per million inhabitants will die on Polish roads, while 27 people per million inhabitants will die on Slovak roads.
\end{abstract}

Keywords: road accidents; road fatalities; road safety

JEL Classification: $R 42 ; R 11 ; 018$

\footnotetext{
${ }^{*}$ Corresponding author: dfrej@tu.kielce.pl
} 


\section{Introduction}

Road accidents are considered to be one of the most important social problems of modern times (Lozia, 2020; Bertoli and Grembi (2021); Qureshi et al. (2020); Ali et al. (2021). According to the World Health Organization (WHO), 1.35 million people die in road accidents each year, and from 20 to 50 million people are seriously injured (Huang et. al, 2018; WHO, 2021). According to WHO statistics, as much as $93 \%$ of road fatalities worldwide occur in low- and middle-income countries (WHO, 2018). Road accidents are currently the leading cause of death for both children and young people aged 5-29. Road traffic accident death is, according to WHO, the eighth leading cause of death in all age groups. Every year more people die in road accidents than in patients with HIV/AIDS, tuberculosis and polar diseases (Frej et.al, 2020; Kalašová et. al, 2020). Moreover, every road accident generates economic losses for the state. These losses result from the costs of treatment as well as the lost productivity of people killed in accidents and people permanently unable to work. Road accidents in most EU countries cost around 3\% of gross domestic product. It should be noted that WHO is a leading international organization that cooperates with the UN regional commissions for road safety. Moreover, it is the WHO that presides over the United Nations cooperation for road safety (Frej and Ludwinek, 2020; Terrich et. al, 2020). WHO oversaw the actions of over 110 countries around the world from 2011 to 2020 in terms of changes to the "decade of action" and the "zero vision". WHO plays a key role in driving global efforts to increase road safety from the highest political levels to the development and dissemination of good practice in prevention, data collection and trauma care Caban et.al, 2019, Oskarbski, et.al, 2016).

According to the WHO, road accidents are avoidable. The approach to reducing the incidence of road accidents is based on Sweden's "Vision Zero". This strategy has a longterm vision of no fatalities and no serious injuries in the transport system. By running a safe road accident prevention system, and in the event of its occurrence, ensuring the impact force insufficient to cause serious injuries (Ren and Ren, 2019; Ke et.al, 2018). Scientists from WHO believe that a road accident can only be prevented by the government's effective action on road safety in a holistic issue. Undoubtedly, this type of involvement requires efficient activities of many sectors such as transport, police, health care, education and activities related to the safety of roads, vehicles and road users (Frej, et al., 2020)

According to WHO, the tightening of road rules is necessary to improve road safety. Unfortunately, too many countries still have regulations that are inadequate to the state of road safety. The basic rules that require tightening include excessive speeding, driving under the influence of alcohol or drugs. Increasing road safety is related to the observance of road regulations by road users, improvement of road infrastructure and improvement of car safety (OECD, 2006). In order to improve safety, in the years 2020-2030, the European Council and the European Parliament introduced provisions on compulsory equipment for new cars sold in the EU. According to the adopted regulations, all motor vehicles in the EU Member States would have to be equipped with safety elements (GAMBIT; Sotheary and Times, 2020):

- speed adaptation system,

- facilitations in the installation of breathalyser's that block the ignition,

- driver drowsiness and attention monitoring system,

- driver distraction detection system,

- emergency stop signal,

- emergency detection of objects while reversing,

- event data recorder,

- tire pressure monitoring system. 
Moreover, the regulations stipulate that passenger cars and vans must be equipped with additional safety elements, such as (Speer crash risk; Frej et. al; 2020):

- Advanced emergency braking systems,

- Emergency lane maintenance systems,

- Increased head impact protection zones designed to mitigate injuries in collisions with unprotected road users (pedestrians and cyclists).

On the other hand, in the case of road infrastructure, new sections of expressways and motorways are built each year in the Member States of the European Union, which allow drivers to move only in one direction. Restricting vehicle movement in two directions, separating road lanes from each other, reduces frontal and side accidents (Speer crash risk).

It should be noted that the European Union plans to create a large transport network by 2050 in the territory of 28 Member States (Fig. 1). The main pillar of the transport network will be the new core network (TEN-T), based on 9 main transport corridors. According to the plans, Poland and Slovakia will be crossed by two transport corridors that will connect two Member States in terms of the exchange of goods on the international arena (Jurecki, 2020; Statystyka, 2020).

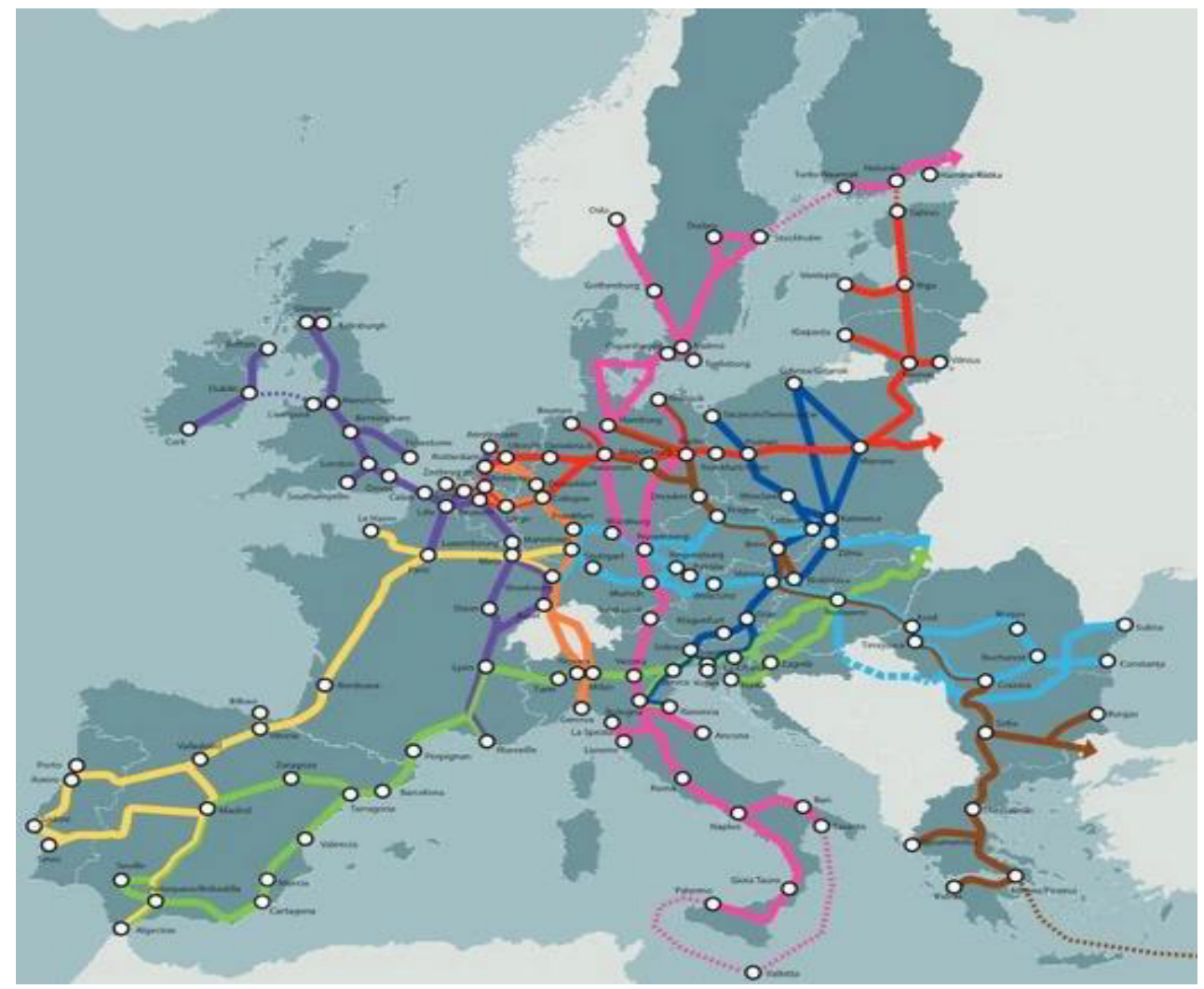

Figure. 1. Transport corridors in the European Union: Baltic-Adriatic corridor (navy blue), North Sea-Baltic corridor (red), Mediterranean corridor (green), East-Mediterranean corridor (brown), Scandinavian-Mediterranean corridor (pink), the Rhine-Alpes corridor (orange), the Atlantic corridor (yellow), the North Sea-Mediterranean corridor (purple), the Rhine-Danube corridor (blue).

Source: Forsal.pl, (2013). 


\section{Road accident statistics}

Road transport plays a significant role in Poland and Slovakia. About 38 million people live in Poland, while in Slovakia about 5.5 million people. The planned length of expressways in Poland at the end of 2020 will be $8,177 \mathrm{~km}$, including approximately 2,100 km of motorways and 6,077 km of expressways. According to the World Economic Forum, in 2020 the quality of roads places Poland in 20th place in Europe and 57th in the world. However, the total length of roads in Slovakia is $42,993 \mathrm{~km}$. With a paved surface of $37533 \mathrm{~km}$ (including $415.5 \mathrm{~km}$ of motorways and $259 \mathrm{~km}$ of expressways) and an unpaved area of 5,460 km (Statystyka, 2020; MI SR, 2021).

It should be noted that in the case of the European Union in 2010-2020 the number of fatal road accidents decreased by $36 \%$. In 2020, 42 people are killed per million inhabitants in the EU. In Slovakia, in 2020, the rate was 45 people killed per million inhabitants. On the other hand, in the case of Poland, this indicator is 65 people killed per million inhabitants. The continuing high number of road accidents is not only an analysis of the existing situation, but also a warning for road users and entities responsible for road safety. Annual police reports and inspections carried out by the Supreme Audit Office alert that the road traffic hazard in Poland is too high. Poland is included in the European Union countries with a high number of road casualties per million inhabitants. Figure 2 presents a graph showing the number of people killed in road accidents per million inhabitants.

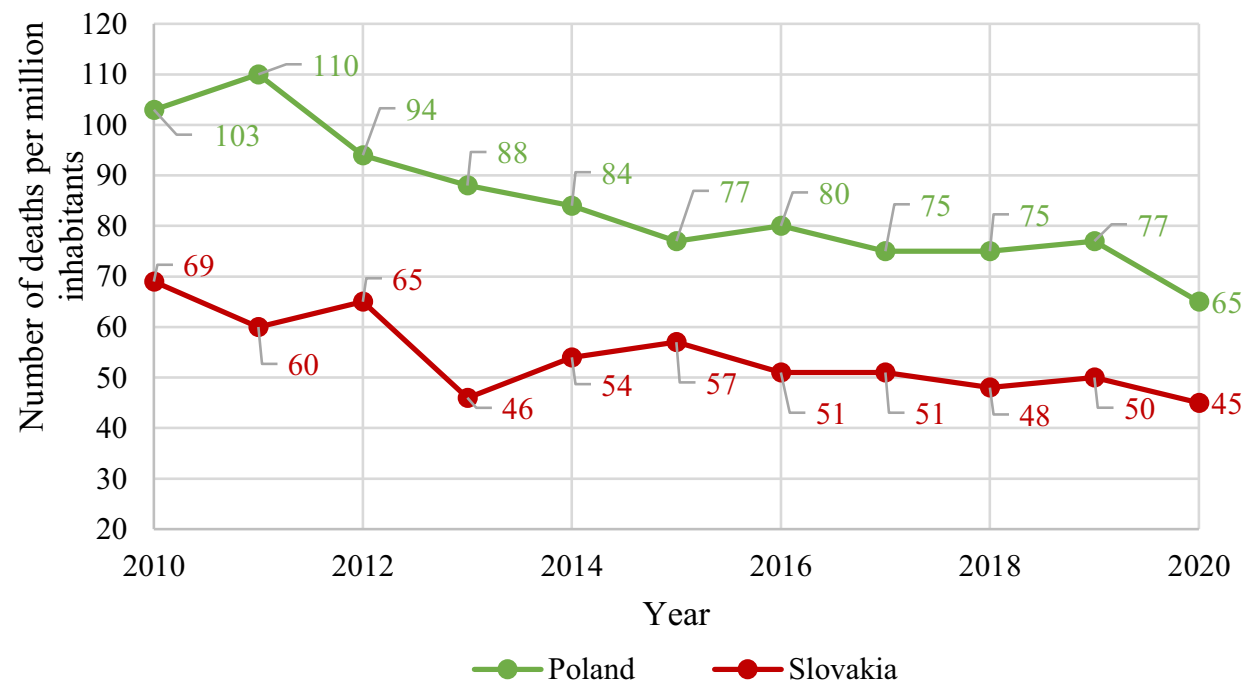

Figure. 2. The number of people killed in road accidents per one million inhabitants in 2010-2020.

Source: Statystyka, 2020; MI SR, 2021

When considering the number of fatalities in terms of the ratio of victims to the number of passenger cars, a similar downward trend can be observed in 2016-2019 between Poland and Slovakia (Fig. 3). In Poland in 2019, 12 people per 100,000 passenger cars died in road accidents, while in Slovakia 11 people. 


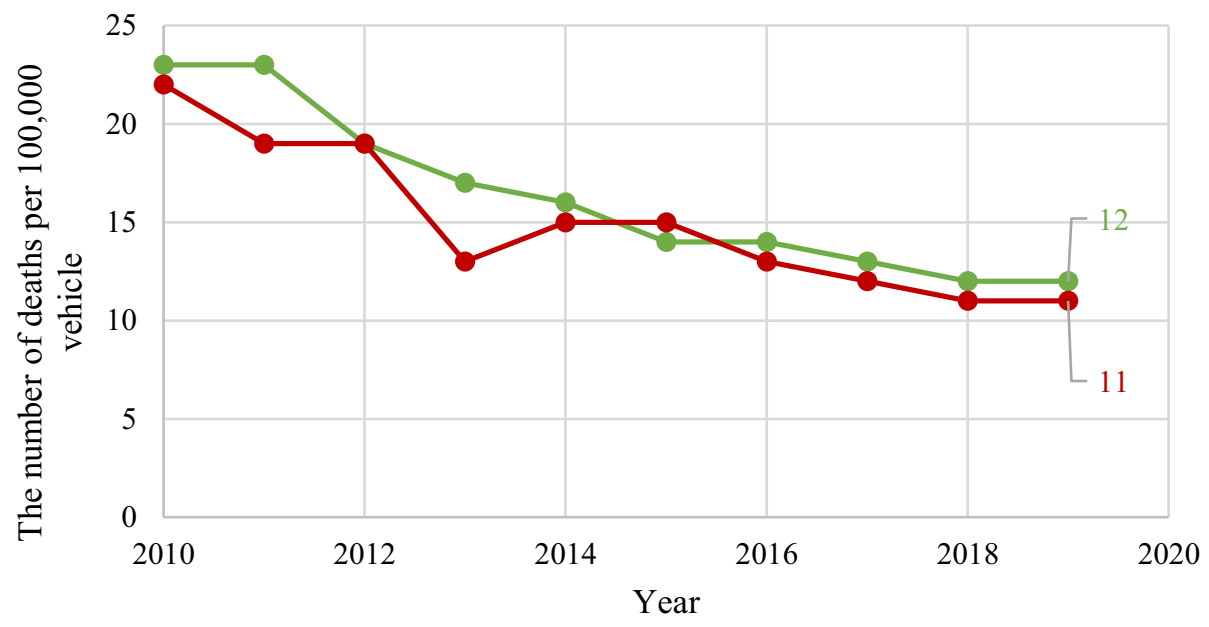

$\longrightarrow$ Poland $\rightarrow$ Slovakia

Figure. 3. The number of people killed in road accidents per 100,000 passenger vehicle in 20102020.

Source: Statystyka, 2020; MI SR, 2021

In the last decade, the number of road accidents in Poland decreased by $40 \%$, and in Slovakia by $45 \%$. Figure 4 shows the number of car accidents in Poland and Slovakia in 2010-2020.

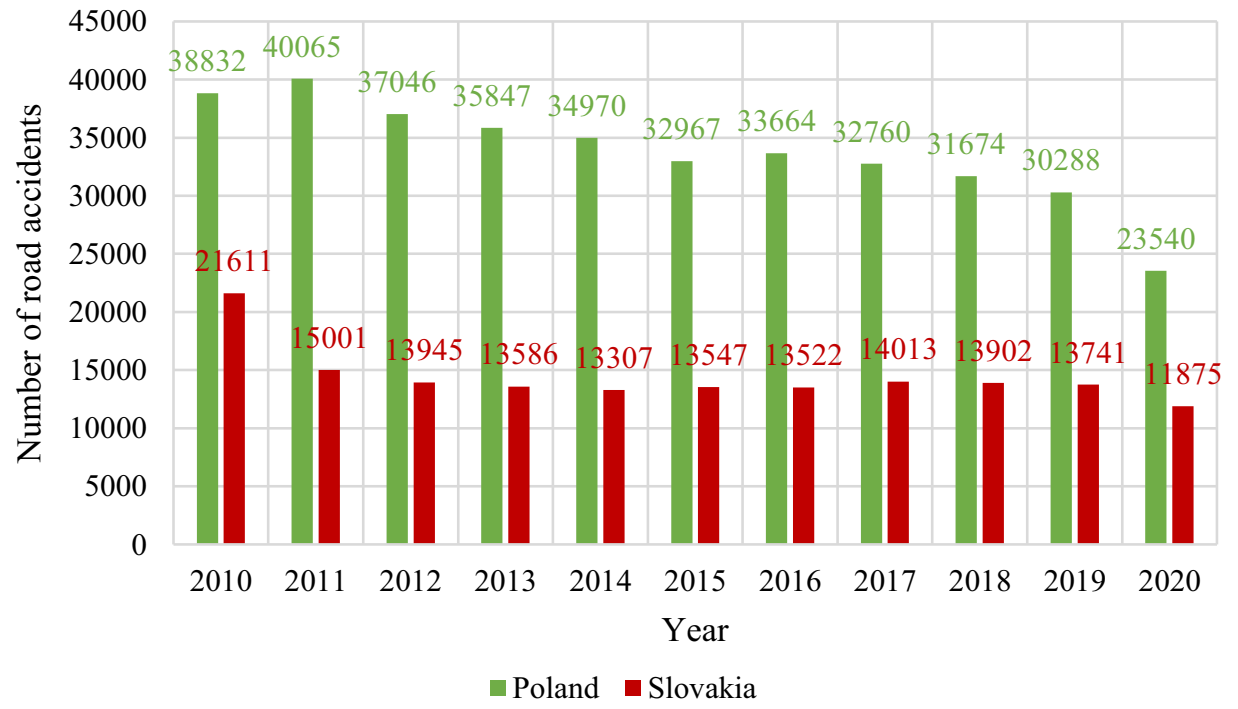

Figure. 4. Number of car accidents in Poland and Slovakia in 2010-2020.

Source: Statystyka, 2020; MI SR, 2021

The number of fatalities in road accidents, both in Poland and Slovakia, maintains a downward trend each year. In total, as many as 352,836 people died in road accidents in Poland in 2010-2020, while in Slovakia only 2,911 people. The total number of road accident 
victims in Slovakia in 2010-2020 is comparable to the number of road accident victims in Poland during one year. In Poland, over the decade, the number of road fatalities decreased by $36 \%$, while in Slovakia by $35 \%$ (Fig. 5 ).

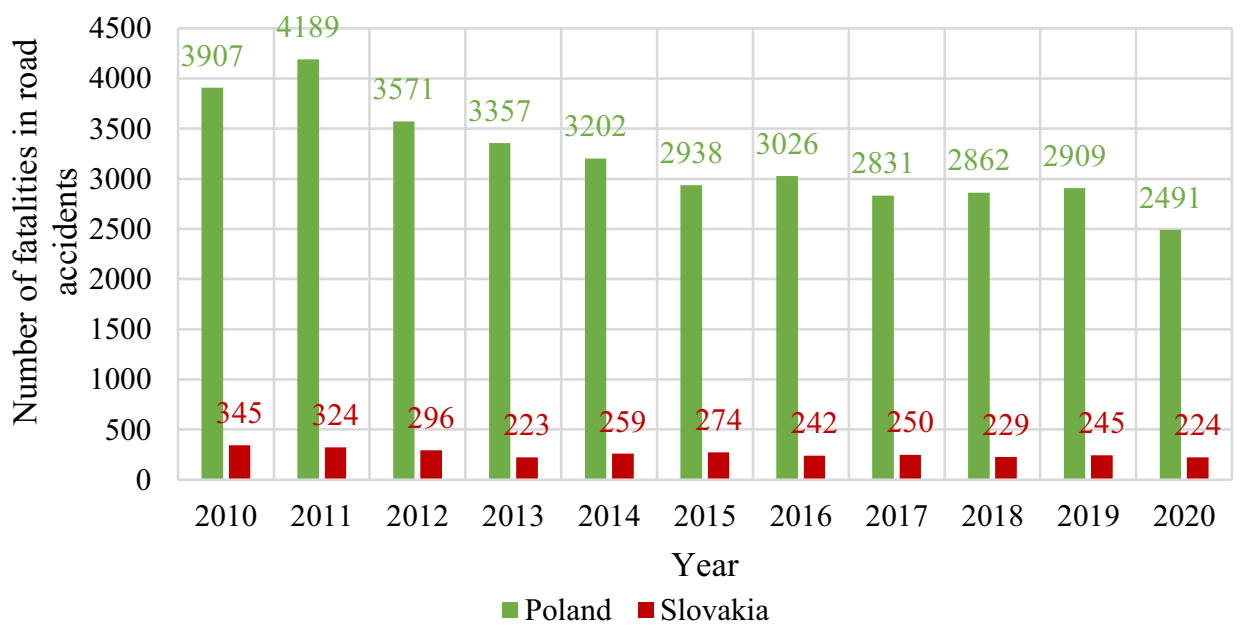

Figure. 5. Number of fatalities in road accidents in Poland and Slovakia in 2010-2020.

Source: Statystyka, 2020; MI SR, 2021

The highest number of road accidents in Poland in 2020 took place between 4:00 p.m. and 8:00 p.m. (6,759 road accidents), while in Slovakia between 12:00 and 4:00 p.m. (2,639 road accidents). It should be noted that approximately $60 \%$ of road accidents occur in families from 12 to 20 (Fig. 6).

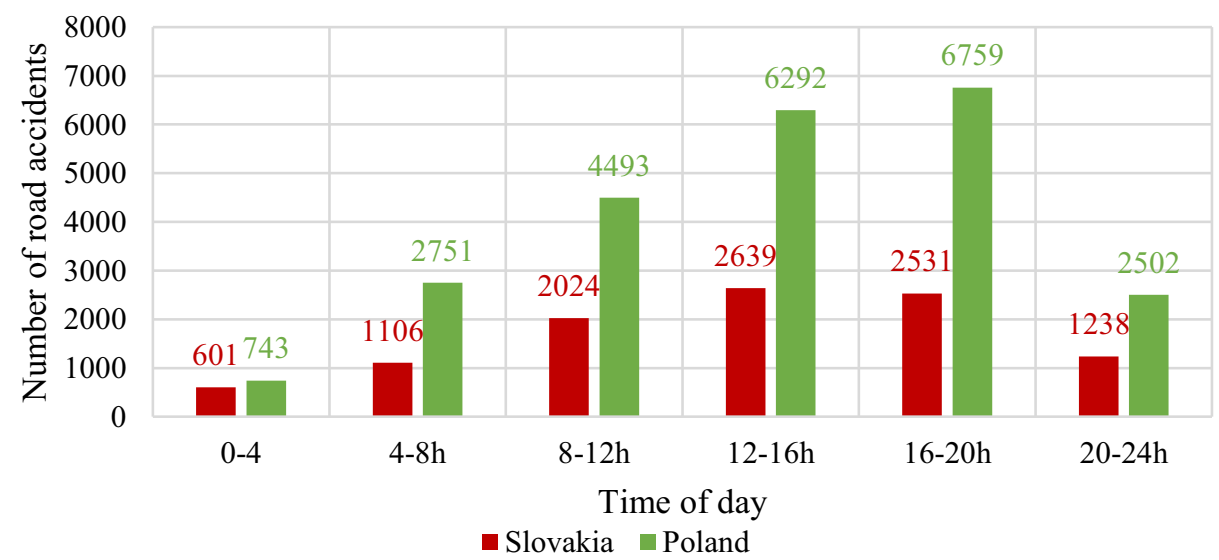

Figure. 6. Number of road accidents in Poland and Slovakia in 2020, taking into account the time of day.

Source: Statystyka, 2020; MI SR, 2021

The number of fatalities in road accidents in Poland and Slovakia in terms of the time of day is presented in Figure 7. It should be noted that the largest number of fatalities in road accidents in Poland and Slovakia in 2020 took place between 4:00 pm and 8:00 pm. About $30 \%$ of all fatalities died during this time frame. On the other hand, the smallest number of people died in a road accident during the night. 


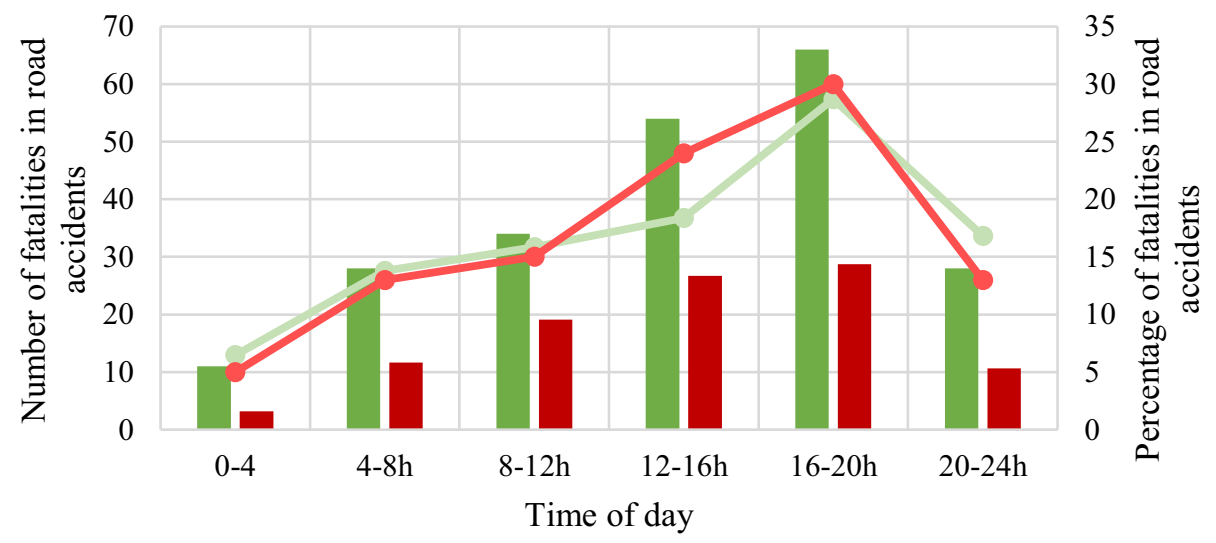

Poland Slovakia $\longrightarrow$ Poland \% $\quad-$ Slovakia \%

Figure. 7. Number of fatalities in road accidents in Poland and Slovakia in 2020, taking into account the time of day.

Source: Statystyka, 2020; MI SR, 2021

Road accidents in terms of days of the week in 2020 in Poland and Slovakia proceed with almost the same intensity. Most accidents occurred on Friday in Poland (16.7\%), and in Slovakia (17.1\%). The fewest accidents occur on Sundays in Poland $11.2 \%$, in Slovakia $10.7 \%)$.

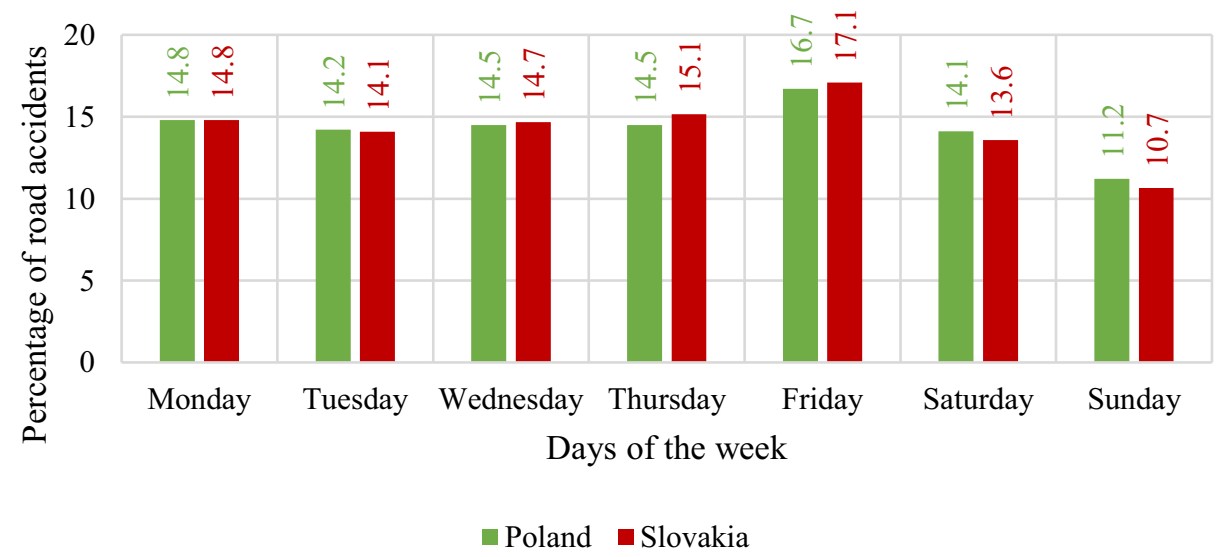

Figure. 8. The number of road accidents in Poland and Slovakia in 2020, taking into account the day of the week.

Source: Statystyka, 2020; MI SR, 2021

In 2019, 74.2\% of road accidents occurred in the Built-up Area in Slovakia, this number decreased to $72.7 \%$ in 2020 . In 2019 , in Poland, as much as $70.5 \%$ of road accidents took place in built-up areas, this number in 2020 decreased to $69.3 \%$ (Fig. 9). In addition, in 2020 in Slovakia, 63.8\% (65.7\% in 2019) of all fatalities occurred in undeveloped land, and in Poland, 56.5\% (59.5\% in 2019). Figure 10 shows the percentage breakdown of fatalities in Poland and Slovakia in 2019-2020, taking into account the area of the accident. 


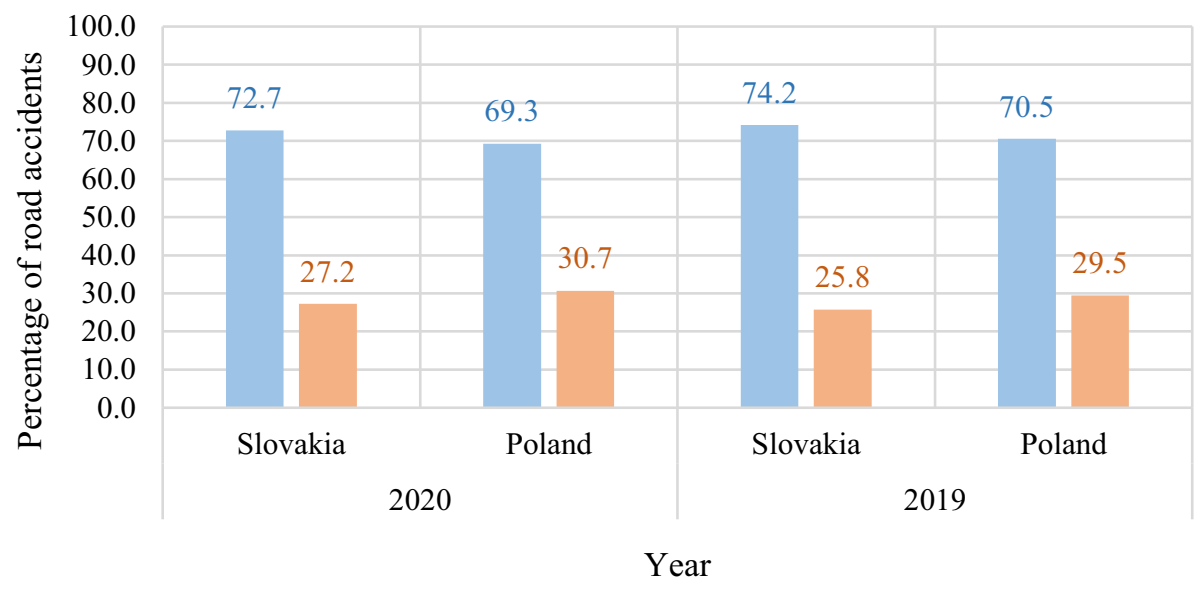

Built-up area $\quad$ Undeveloped area

Figure. 9. Percentage of road accidents in Poland and Slovakia in 2019-2020, taking into account the area of the accident.

Source: Statystyka, 2020; MI SR, 2021

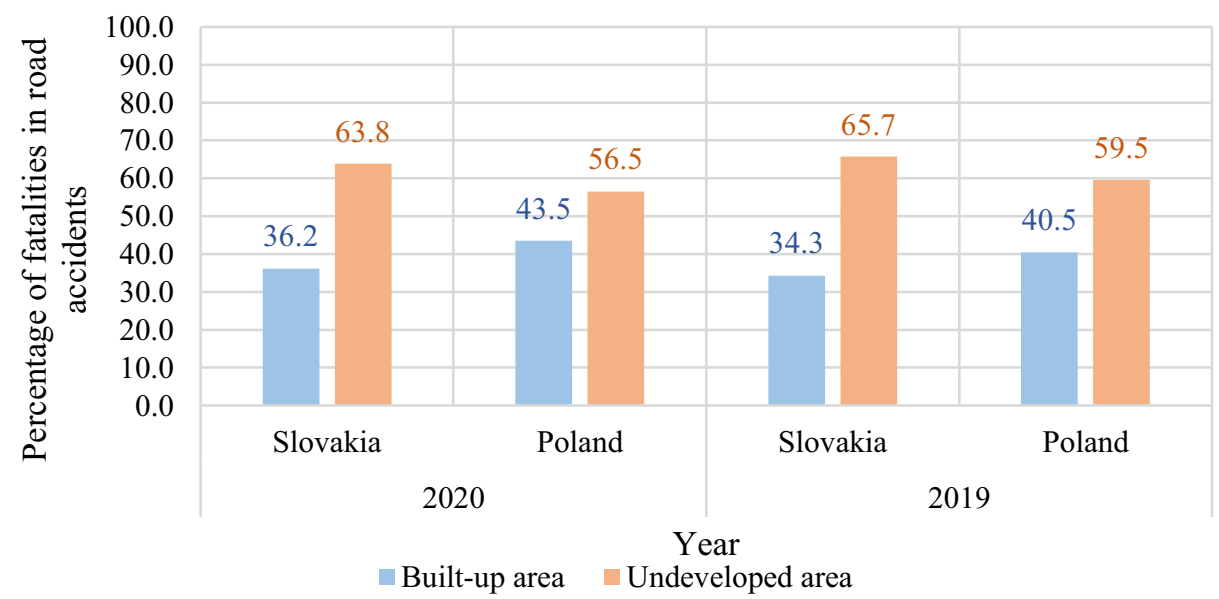

Figure. 10. Percentage of fatalities in road accidents in Poland and Slovakia in 2019-2020, taking into account the area of the accident.

Source: Statystyka, 2020; MI SR, 2021

\section{Results and Discussion}

The available data on road accidents and the number of registered motor vehicles in Poland and Slovakia form the basis for the forecast of the number of road accidents for the following years. Forecasts of road accidents in Poland for 2020-2030 show a significant decrease in the number of road accidents from 23.5 thousand in 2020 to 13.5 thousand in 2030. This forecast shows a year-to-year decrease by an average of $7 \%$ of road accidents. Projections of road accidents in Slovakia for 2020-2030 show a decrease in the number of road accidents 
from 11.8 thousand in 2020 to 7.2 thousand in 2030 (Fig. 11). This forecast shows an annual decrease from year to year by an average of $8 \%$ of road accidents in Slovakia.

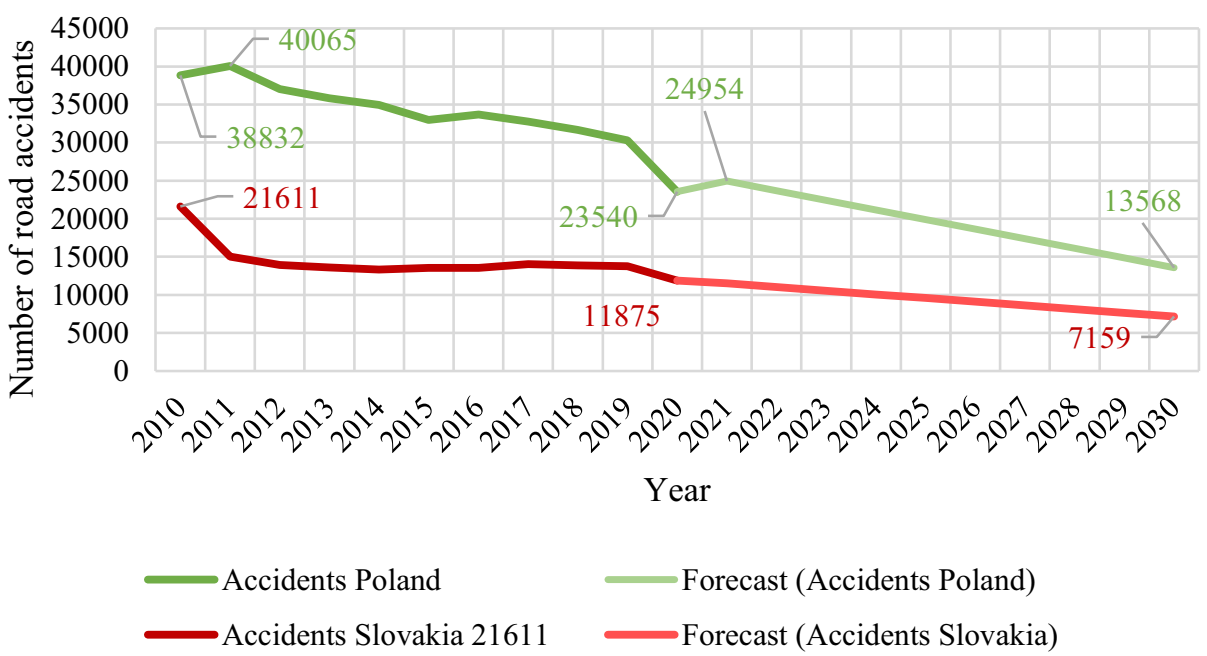

Figure. 11. Forecast of road accidents in Poland in 2020-2030.

In the case of the number of road fatalities per million inhabitants, the forecasts for 2020 2030 assume a decrease in Poland from 62 deaths per million inhabitants in 2020 to 29 deaths per million inhabitants in 2030 (Fig. 12). This forecast assumes a decrease of over $50 \%$ in the number of victims killed in the next decade. However, in the case of Slovakia, the forecasts assume a decrease in the number of victims killed from 44 per million inhabitants to 27 per million inhabitants (Fig. 13).

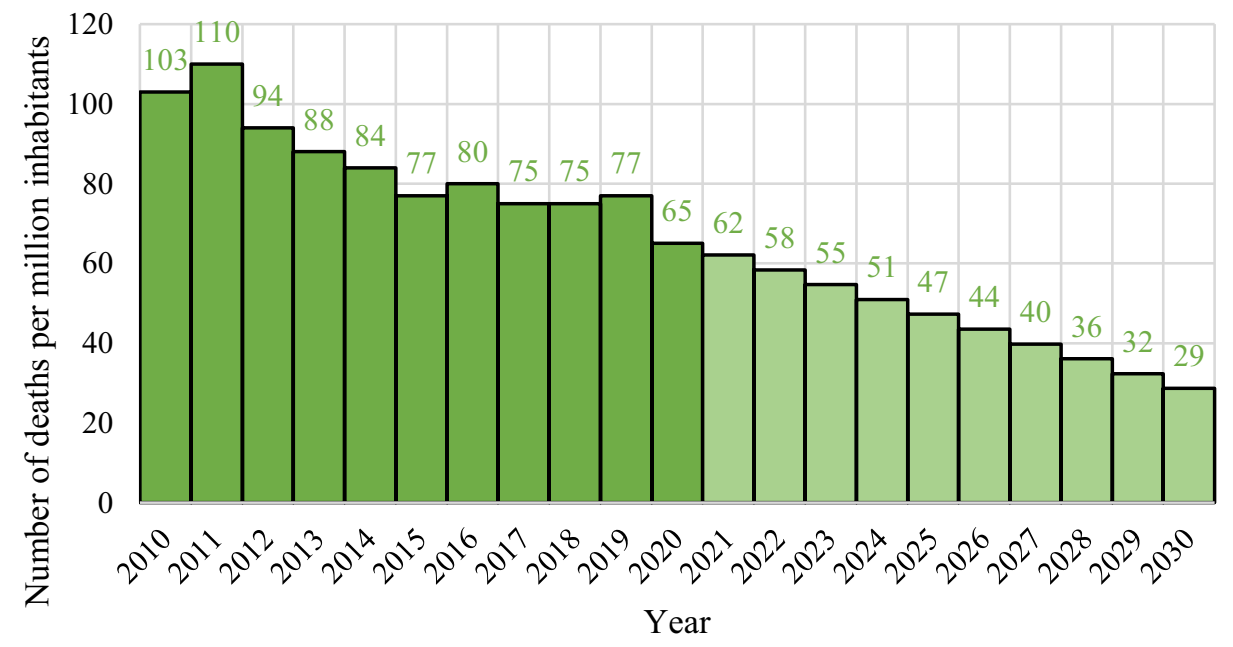

口Poland $\quad$ GForecast (Poland)

Figure. 12. Forecast of the number of people killed in road accidents in Poland per one million inhabitants in the years 2020-2030. 


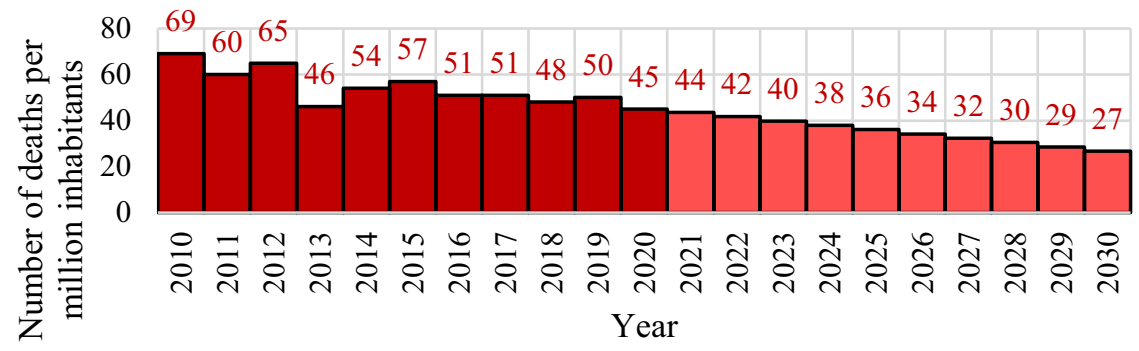

Slovakia $\mathbf{D F o r e c a s t}($ Slovakia)

Figure. 13. Forecast of the number of people killed in road accidents in Slovakia per one million inhabitants in the years 2020-2030.

\section{Conclusions}

Improving the safety of road users and reducing the number of road accidents and fatalities is possible thanks to the government's holistic road safety policy. Therefore, the authorities of the European Union approved a plan to extend the list of mandatory equipment for new passenger cars. From 2022, intelligent speed limiters and lane assist are to be included in the standard equipment of a passenger car. These changes are introduced as part of Vision Zero, in which the European Union has committed to reducing the number of road fatalities from 25,000 (2019) to 12,000 in 2030. And the next step of the Vision Zero strategy is to completely eliminate fatalities as a result of a road accident by 2050 .

The forecasts for 2020-2030 made on the basis of the collected statistical data on road accidents in the years 2010-2020 show a further downward trend in the number of road accidents. According to statistical forecasts, this number will decrease by $7 \%$ each year on Polish roads, and by $8 \%$ on Slovak roads. In 2030, there may be only 13.4 thousand road accidents in Poland, while in Slovakia up to 7.2 thousand road accidents.

\section{References}

1. Ali, F., Ali, A., \& Kwak, K. S. (2021). Traffic accident detection and condition analysis based on social networking data. Accident Analysisi and Prevention, 151.

2. Bertoli, P., \& Grembi, V. (2021). The political cycle of road traffic accidents. Journal of Health Economics, 76.

3. Caban, J., Turski, A., Nieoczym, A., Tarkowski S., \& Jereb B. (2019). Impact of specific factors on the state of the tire pressure value. The Archives of Automotive Engineering Archiwum Motoryzacji, 85(3), 137-148.

4. Ding, Z. (2010). The Enlightenment of Vision Zero to China's Road Safety Management. WASE International Conference on Information Engineering, 352-355.

5. Forsal.pl (2013, November 20). Oto główne szlaki komunikacyjne UE. Bruksela chce je zbudować do 2050 roku. https://forsal.pl/artykuly/746994,oto-glowne-szlakikomunikacyjne-ue-ten-t-transport.html

6. GAMBIT (2005). Krajowy Program Poprawy Bezpieczeństwa Ruchu Drogowego 20052007-2013 GAMBIT 2005, Warszawa. http://v000384.home.net.pl/download /pdf/Gambit_2005_RM.pdf 
7. Huang, X., Zhang, M., Wang, J., \& Chen, J. (2018). Study on Law of Scenario Evolution Based on Accident Statistics of Hazardous Chemicals Transportation. 2018 IEEE International Conference of Safety Produce Informatization (IICSPI), 80-83.

8. Frej, D., Grabski, P., \& Szumska, E. (2020). Analysis of the Causes of Vehicle Accidents in Poland in 2009-2019. LOGI - Scientific Journal on Transport and Logistics, 11, 76-87.

9. Frej, D. P., \& Ludwinek, K. (2020). Analysis of road accidents in 2002-2019 on the example of Poland. The Archives of Automotive Engineering - Archiwum Motoryzacji, $89(3), 5-18$.

10. Jurecki, R. S. (2020). Analysis of Road Safety in Poland after Accession to the European Union. Communications - Scientific Letters of the University of Zilina, 22(2), 60-67.

11. Kalašová, A., Čulík, K., \& Hájnik, A. (2020). Young Drivers and Their Risky Behavior on the Roads. XII International Science-Technical Conference Automotive safety, 1-6.

12. Ke, Q., Renxiang, B., Yong, L., \& Kaige, D. (2018). Ship Collision Avoidance Timing Based on Subjective Collision Risk. 3rd IEEE International Conference on Intelligent Transportation Engineering (ICITE), 170-173.

13. Kharat, S. B., \& Sawant, S. D. (2017). Travolution: System for road safety. International Conference on Intelligent Computing and Control Systems (ICICCS), 1123-1125.

14. Lozia, Z. (2020). Can anything optimistic be found in the statistics of road accidents in Poland in 1975-2018?. 2020 XII International Science-Technical Conference AUTOMOTIVE SAFETY, 1-4.

15. MI SR. (2021). Dopravná nehodovost' v Slovenskej republike. https://www.minv.sk/?statisticke-ukazovatele-sluzby-dopravnej-policie

16. OECD (2006, September 28). Governments should tighten rules for young drivers to cut road deaths. https://www.oecd.org/general/governmentsshouldtightenrulesforyoungdriverstocutroad deaths.htm

17. Oskarbski, J. Zawisza, M. \& Zarski, K. (2016). Automatic incident detection at intersections with use of telematics. Transport Research Arena TRA2016. In: Rafalski, L., Zofka, A., ed., Transportation Research Procedia, 14, 3466-3475.

18. Qureshi, A. I., Huang, W., \& Suri, M. F. K. (2020). Mandated societal lockdown and road traffic accidents. Accident Analysisi and Prevention, 146.

19. Ren, B., \& Ren, J. (2019). Research on calculation model of vehicle collision avoidance based on safe collision time. 2019 IEEE 2nd International Conference on Automation, Electronics and Electrical Engineering (AUTEEE), 101-104.

20. Sotheary, P., \& Times, K. (2020, April 30). Authorities tightening road traffic laws. https://www.khmertimeskh.com/718534/authorities-tightening-road-traffic-laws/

21. Statystyka (2020). Wypadki drogowe - raporty roczne. https://statystyka.policja.pl/st/ruch-drogowy/76562, wypadki-drogowe-raportyroczne.html

22. Terrich, T., \& Žák, P. (2018). Analysis of Traffic Accidents as a Part of Methodology for Selecting a Lighting Class for Road Lighting. VII. Lighting Conference of the Visegrad Countries (Lumen V4), 1-5.

23. WHO World Health Organization (2018). Global status report on road safety 2018.

24. WHO World Health Organization (2021, June 21). Road traffic injuries. https://www.who.int/news-room/fact-sheets/detail/road-traffic-injuries 